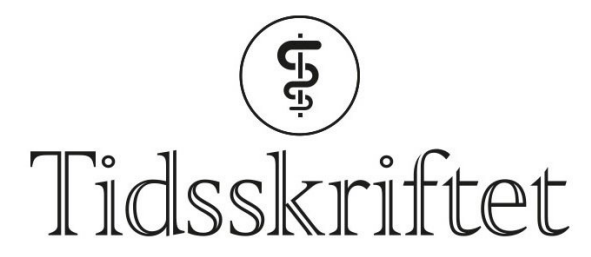

DEN NORSKE LEGEFORENING

\title{
Stetoskopets far
}

TIDLIGERE I TIDSSKRIFTET

JULIE DIDRIKSEN

Tidsskriftet

Det er en grunn til at det alltid henger et stetoskop over nakken til skuespillere eller modeller som skal portrettere leger. Det er lite som er så symboltungt for det å være lege som dette karakteristiske verktøyet. Under følger en notis fra Tidsskriftets utgave 16-17/1920, altså litt over 100 år etter at en lege fikk en viktig idé på en spasertur i Frankrike (Tidsskr Nor Lægeforen 1920; 40: 583 ).

Fra et leketøi. Det er netop 100 aar siden, at den kjendte Réné Théophile Hyacin Laennec gjorde en iagttagelse, som skulde faa den aller største betydning for den interne medicin. Han saa nemlig, at nogen barn, som lekte i haven ved Louvre, lyttet til overførelse av lyd gjennem et stykke træ. Herved kom han paa den tanke at benytte en lignende metode til at høre anndelyden, naar han undersøkte patienternes lunger. Han gik hjem og laget sig en fast papirrull, og med denne eksperimenterte han saa i sin sykeavdeling i Hôpital Necker. Fra dette tilfælde i Louvrehaven skriver altsaa det moderne stetoskop sig, et instrument som er uundværlig i den moderne medicinske praksis.

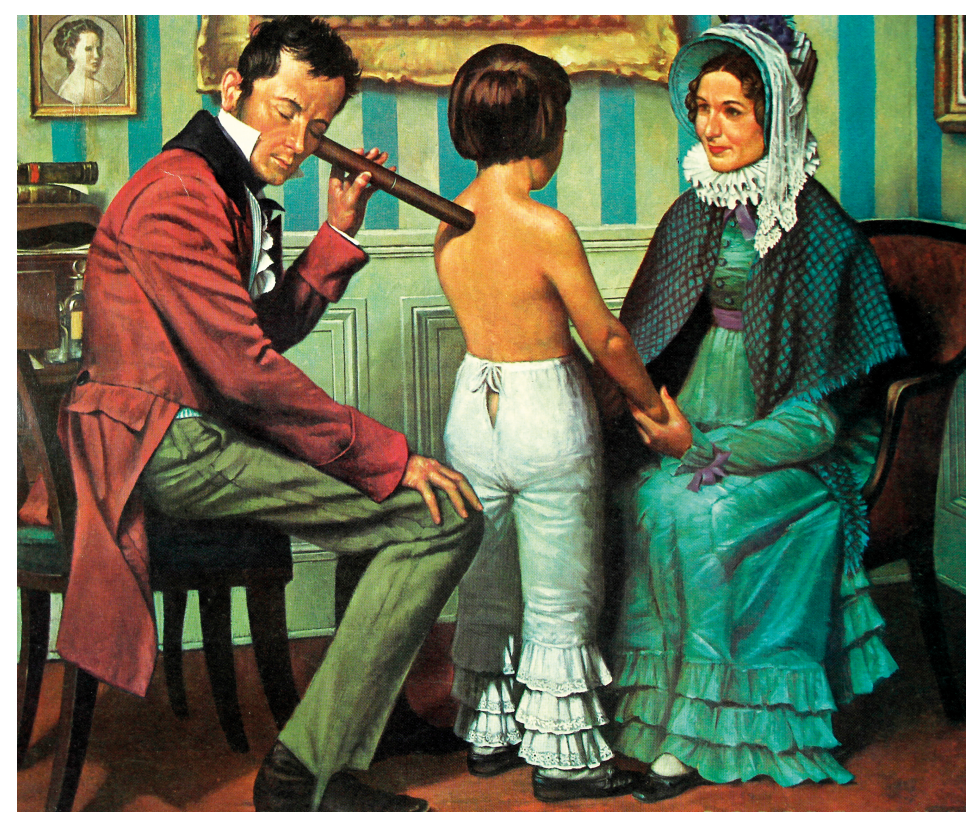

Laënnec og stetoskopet, malt av Robert A. Thom i 1952. Illustrasjonsfoto: FotoFlirt / Alamy Stock Photo

Laennecs første stetoskop var ikke saa litet forskjellig fra de nu brukelige, især naar man tar hensyn til, at det binaurikulære vel nu anvendes av de fleste læger verden over. 
Et instrument som er uundværlig i den moderne medicinske praksis

Paa Laennecs tid var skiddenfærdigheten i hospitalerne saa stor, at lægerne kviet sig for at lægge øret til, naar der skulde gjøres en brystundersøkelse, og dette har formodentlig ogsaa været en medvirkende aarsak til, at han grep den idé, som barnenes lek gav ham. Laennec blev født i Quimper i Bretagne $17 \mathrm{de}$ februar 1781 og vokste op under de mest urolige aar i Frankrikes historie. Han studerte medicin i Paris og tok sin doktorgrad i 1804. Han døde 13de august 1826, 45 aar gammel, i den gamle by i Bretagne, hvor han først saa dagens lys.

(Long Island Med.Journal, nr. 41920).

Publisert:3. august 2020. Tidsskr Nor Legeforen. DOI: 10.4045/tidsskr.20.0087

(C) Tidsskrift for Den norske legeforening 2020. Lastet ned fra tidsskriftet.no 